\title{
The emergence of Cambodian civil society within global educational governance: A morphogenetic approach to agency and structure
}

This paper uses Margaret Archer's morphogenetic approach to analyze the emergence of civil society within global educational governance. The purpose is to understand the intersection of historical structures with global actors and spaces that have accompanied the globalization of education. Based on findings from a study on the impact in Cambodia of the Civil Society Education Fund-sponsored by the Global Campaign for Education - we first identify the relevant socio-cultural, political-economic, and governance structures within which the politics of education is embedded in Cambodia. Then, we detail the relational processes through which Cambodian civil society has been able to join and, in so doing, modify the structures of education governance. The value of the morphogenetic approach is its treatment of time - that is, the way that it temporarily separates structure and agency in order make possible an analysis of the dynamics of global education governance. While this approach is not new, we suggest that a morphogenetic approach can help in understanding the ways actors come together to create the processes and co-constitute the spaces through which existing educational structures and policies are made and remade across time.

Keywords: Globalization, educational governance, Cambodia, civil society

\section{Introduction}

In his most recent book on cultural flows, Arjun Appadurai (2013) claims a basic problem in the social sciences regards the comparison of social objects within a globalized world where most objects are interconnected. Whereas social scientists have typically viewed social objects as distinct from one another and therefore "unsullied by connectivity" in order to perform comparisons, Appadurai argues an alternative and necessary approach to comparison begins by recognizing "histories produce geographies and not vice versa" (Appadurai, 2013, p. 65). Geographies are understood through the movement of social actors and objects, what Appadurai calls "forms of circulation," and their particular formation at a given point in time, what Appadurai calls "circulation of forms." Such a conceptual formulation recognizes that space, place, and time are diachronic and relational: the constant evolution of history continuously re-constitutes the meaning and formation of objects and actors. The connection between structure and agency is therefore a complex one as they interact and shape each other.

Within contemporary globalization, the geography of the state has been re-scaled and, as such, is continuously in contact with international actors and objects (Lingard \& Rawolle, 2011). Appadurai (2013, p. 69) recognizes this and thus encourages us to conceive of local geographies as at least partially reflective of - or co-constituted by - the global, in that globally circulating policy content or management models, for example, are negotiated into historically shaped localities. The implication is that Appadurai seeks not to examine static objects but rather the relationships among actors and social objects (e.g., policy) and the ways that these actors and objects are globally and locally constituted, constrained and enabled. A further implication is that 
Appadurai's concepts are particularly useful for studies of global education governance and national education policymaking, wherein the above-mentioned issues are central (see, e.g., Larsen \& Beech, 2014; Rizvi \& Lingard, 2010).

Analytically, however, the problem becomes opening up the connection between structure and agency, given their complex and continuous interaction over time. It is on this point that we attempt to make a contribution. We do this by drawing on the work of Margaret Archer (2010a,b), whose morphogenetic approach to social change enables one to productively explore "the interplay between structure and agency and their outcomes" (Archer, 2010b, p. 274). We demonstrate the utility of Archer's approach by applying it to an analysis of the emergence and impact of Cambodian civil society within the education sector. In so doing, we focus on the intersection of historical geographies with the new actors, spaces, and structures that have arisen in tandem with the development of global education governance in recent decades. Ultimately, with regard to education governance arrangements in Cambodia, we explicate processes of emergent structural and agential change - what Archer (2010a,b) calls "morphogenesis." In the end, our purpose is twofold: First, to demonstrate the value of Archer's methods for overcoming analytical problems of continuously re- and co-constituting agents and structures, and, second, to provide new insights - afforded by the morphogenetic approach-into how histories, structures, and social interaction combine in and affect processes of global education governance.

Going forward, the next section characterizes key aspects of global education governance, as relationally constituted by a range of actors and spaces. This section will clarify the larger, global context within which the politics and dynamics of education governance in Cambodia is nested. Then, in section three, we discuss our methods and detail the morphogenetic approach of Archer. Thereafter, the fourth section presents our findings on the emergence, engagement and impact of Cambodian civil society. We then reflect in section five on the nature of - and the lessons from-changes to educational governance structures and processes in the case of civil society emergence in Cambodia. In section six, we conclude by discussing implications and by suggesting future avenues for research and theory.

\section{Dynamics of global education governance}

\subsection{New Actors}

The globalization of educational governance entails the emergence of new actors that construct, constitute, implement, and a/effect education policy within national boundaries (Edwards, 2013; Verger, Novelli, \& Kosar-Altinyelken, 2012). Since a policy is "a web of decisions and actions that allocates values" (Easton, 1959, p. 130), multiple actors are inherently connected as decisions are made. Moreover, the formulation of education policies (and recommendations to that end) outside of national boundaries (i.e., within spaces like the World Bank, United Nations organizations, the European Union, or Pearson's Incorporated) has created a "new global geometry of power" (Rizvi \& Lingard, 2010, p. 172) where relatively new actors compete over various interests. Today we see "polycentric arrangements involving public and private, national and international, government and non-government supra-organizations" constructing education discourse that greatly affects education policy making within national contexts (Rizvi \& Lingard, 2010, p. 117).

The new actors are many and will only be touched upon here. (For a more extensive treatment, see, e.g., Ball, 2012.) Some of the first non-state and/or multi-national actors within education policy making derived from the internationalization movements in the post-World War 
II era. These actors included, for example, the United Nations Educational, Scientific and Cultural Organization (UNESCO) and, beginning in the 1960s, international financial institutions like the World Bank (Jones, 2007a,b). These organizations focused primarily on developing countries, often tying specific education policies to development assistance. Other multi-national organizations include the European Union and the Organization for Economic Co-operation and Development (OECD), the latter controlling the Programme for International Student Assessment that was given in 65 countries in 2012, thus wielding immense influence within policymaking circles worldwide (Sellar \& Lingard, 2013). There are also transnational, private actors like Pearson's (the world's largest education company), public policy research organizations like the Cato Institute, and policy entrepreneurs like James Tooley-all of whom work to advocate and advance their preferred forms of global education policy (Ball, 2012). Each of these actors in different ways influences education policy and are beyond the confines of any one nation state.

Of importance in this paper is the emergence of civil society within educational governance (Mundy \& Murphy, 2001). Verger and Novelli (2012), define civil society as "a very broad and contested category. It includes a big variety of organizations such as international and local NGOs [non-governmental organizations], trade unions, community based organizations, grassroots movements, independent research institutes, etc." (pp. 3-4). Civil society often organizes into coalitions within particular sectors (i.e., education, agriculture, health, etc.), and aims to influence "the agendas and decisions of governmental bodies in relation to a particular issue area or problem" (Verger \& Novelli, 2012 p. 4). Globally, both the process and project of neoliberal globalization, particularly during the 1980s and 1990s, have resulted in "the expansion of transnational (nongovernmental) policy actors in education" (Mundy \& Ghali, 2009, p. 724). We will focus on one particular global coalition of civil society and its manifestation in the Cambodian context.

\subsection{New spaces}

With new actors traveling the world more freely and quickly come new spaces where policy is discussed, influenced, and designed. Since the "mobility turn" (Urry, 2003, p. 157) in the social sciences, there has been "a lessening of interest in social structures, and an increasing emphasis on flows and mobilities...that is, a focus on the 'spatializing' of social relations, on travel and other forms of movement and other transnational interactions and forms of sociality" (Ball, 2012, 5). From this perspective, the mobility of social life corresponds to "the construction of new types of global scalings of dynamics and institutions; other times they continue to inhabit the realm of what is still largely national" (Sassen, 2006, p. 1).

A feature of globalized educational governance has been its "pluri-scalar" nature (Dale, 2005, 2007), as opposed to being state-centric and occurring through the formal processes and within the official spaces of government (Lingard \& Rawolle, 2011). When national education policies are influenced by non-state, multi-national, and transnational actors, "the boundaries between state, economy, and civil society... [become] blurred; there are new voices within policy conversations and new conduits through which policy discourses enter policy thinking; and there is a proliferation of policy networks nationally and globally" (Ball, 2012, p. 9). What was once solely the responsibility of the nation state is being re-scaled to include actors and processes that are simultaneously non-state and non-national.

Civil society itself reflects "pluri-scalar" organization, particularly insofar as it creates "more links at the international level, in parallel to the increasing role of international organizations in the framing of national education policies" (Verger \& Novelli, 2012, p. 5). Indeed, it is increasingly common for coalitions to be made up of members from national and international 
organizations, to receive funding from a wide variety of sources, and for its members to attend meetings around the world. In so doing, civil society influences and is influenced by ideas within and outside national contexts (Mundy \& Murphy, 2001).

\section{Studying geographies of educational governance}

\subsection{Methods}

The present paper is based on research conducted in Cambodia during July and August 2012, and was funded by the Global Campaign for Education (GCE). The research evaluated the impact of the GCE's Civil Society Education Fund (explained later) within Cambodia. Our findings stem from 36 interviews, conversations and focus groups with 38 different individuals. Interviewees included staff and leadership of Cambodia's national coalition of education-related NGOs, known as the NGO Education Partnership (NEP); the GCE Leadership Committee; representatives of NEP member organizations; representatives of multi- and bi-lateral development partners (e.g., UNESCO, World Bank, Japan International Cooperation Agency [JICA], and Asian Development Bank [ADB]); international NGOs; policymakers; leadership from the Ministry of Education, Youth and Sport (MoEYS); representatives of media (radio and TV stations); and members of academia. In addition, internal NEP documents were reviewed and analyzed.

\subsection{Analysis}

In analytical terms, in order to put into practice Appadurai's (2013) conceptualization of local geographies as circumscribed by historical processes and as relationally impacted by global actors and objects, we employ the work of Margaret Archer (2010a, b). As noted previously, Archer's morphogenetic approach to social change provides a way to examine the dynamic interaction of structure and agency over time. Specifically, the morphogenetic approach perceives that "the broader context conditions the environment of actors whose responses then transform the environment with which the context subsequently has to deal, the two jointly generating further elaboration as well as changes in one another" (Archer, 1982, p. 476). In this way, the morphogenetic approach artificially constructs a synchronic moment within an otherwise diachronic environment in order to analyze the changes within social structures by actors and/or vice versa.

To continue with this last point, the value of the morphogenetic approach is precisely its ability to incorporate chronological time into the analysis of structures and agents that are coconstitutive and constantly evolving. ${ }^{1}$ Notably, this approach is in contrast to structuration theory, advanced by Anthony Giddens (1979). Although structuration theory also recognizes the theoretical proposition of the co-constitution between structure and agency (what Giddens calls "the duality of structure"), we suggest that it lacks analytic purchase because "the "duality of structure' insists upon their [i.e., structure and agency] temporal simultaneity" (Wilmott, 2002, p. 39; see also Archer, 1982).

Unlike structuration theory, the morphogenetic approach allows for the analysis of structure and agency at different time intervals, even though the two are interrelated,

\footnotetext{
${ }^{1}$ While the morphogenetic approach treats time as chronological, it should be noted that other notions exist, such as the "unfolding" of time in a Deleuzian sense (Webb \& Gulson, 2013) or even as "untimely" in a Platonist sense (see Bartlett, Clemens \& Roffe, 2014).
} 
interconnected, and co-constitutive. ${ }^{2}$ It does this by purposefully separating structure and agency "to examine their interplay in order to account for the structuring and restructuring of the social order" (Archer, 2010b, p. 275). The key is to begin with notion that structures and agents develop and evolve over chronological time such that structure always pre-dates any action that attempts to transform it (this is the history in Appadurai's formulation). By extension, emergent structuresi.e., what results from "structural elaboration" (Archer, 2010b) - post-date action. This recognition of a temporal difference between structure and agency within the morphogenetic approach is captured in Figure 1 where " $T$ " stands for time in a chronological sense.

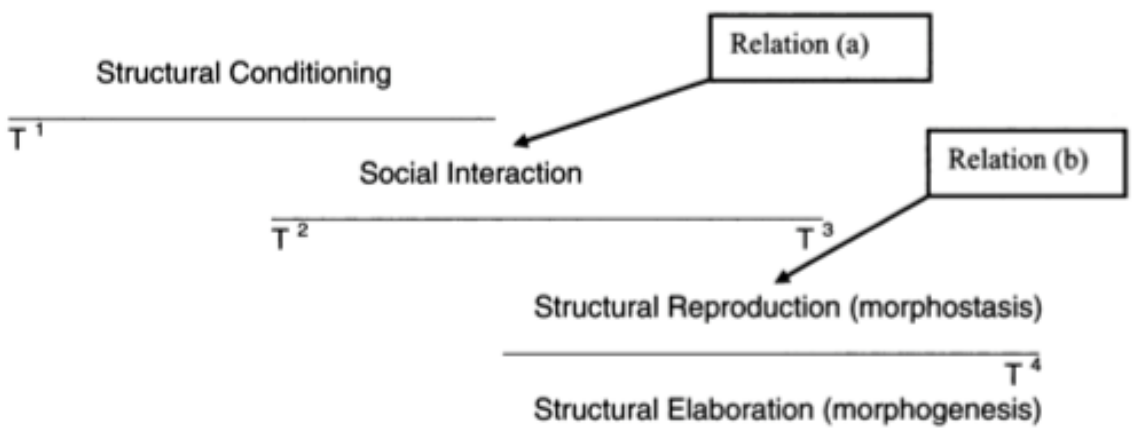

Figure 1: The morphogenetic sequence (Source: Archer, 2010b)

Because the morphogenetic sequence separates the development of structure and agency over time, it is necessary to understand the "structural conditioning" that pre-dates the action under investigation. Then, during "social interaction," agents relate to other agents who interact with the "structural conditioning." Principally, two outcomes can result from this process of interaction (i.e., social relation). On one hand, there is structural reproduction of the social order (i.e., "morphostasis"), while on the other hand the social order experiences some degree of modification through structural elaboration (i.e., "morphogenesis"). In both cases, with the passage of time and action, a new structure results within which future moments of agential (non)change happen. Thus, with reference to Figure 1, $T_{4}$ in first sequence becomes $T_{1}$ in the next sequence. This is how the morphogenetic approach opens for analysis the cycle of events and actions that relationally constitute the structures and spaces in which subjects act, a cycle which would otherwise remain analytically inaccessible.

In terms of the present essay, the morphogenetic approach is also useful because it provides a manner in which to examine the dynamics of global education governance. The researcher is tasked, first, with identifying the structural conditions within which actor agency is embedded, second, with unpacking the social interaction and processes through which actors attempt to change those structural conditions and, third, with what the outcome of the process of change or non-change is.

\section{The Cambodian case of civil society in education}

${ }^{2}$ Appadurai's (2013) conception of time is contained in the term "history." History is chronological time writ large and implies that the co-constitution of structures and agency must be understood through specific temporalities. Appadurai's earlier work has not always used this conception of history (see Graeber, 2001, pp. 33-34). 


\subsection{Structural conditioning}

\subsubsection{Socio-cultural elements}

The contemporary Cambodian context is the result of a particular set of circumstances and developments that began under French colonialism and proceeded through multiple systems of governance, genocide, international isolation, and then an international/Western effort to rebuild, liberalize, and democratize the country (Ayers, 2000). One must begin by mentioning the interplay among multiple structural forces that led to the genocidal atrocities of the Khmer Rouge in the 1970s: the emergence of a socialist movement in rural Cambodia in the 1960s that had global connections (albeit mainly with Vietnam), the official state neutrality during the Cold War, and the escalation of the US war in Vietnam that resulted in a "secret" bombing of Cambodian territory (see Vickery, 2010). The devastation of the country cannot be understated when the Khmer Rouge lost control of governance in 1979:

[Cambodia] had no currency, no markets, no financial institutions and virtually no industry. There was no public transport system; no trains ran and the roads were damaged and unrepaired. There was no postal system, no telephones and virtually no electricity, clean water, sanitation or education. (Mysliveic, 1988, p. 11)

\subsubsection{Political economy elements}

In the post-Khmer Rouge period, Cambodia (known at this time as the People's Republic of Kampuchea) was internationally isolated between 1979 and 1989 because the West perceived the Vietnamese liberation of Cambodia from the Khmer Rouge as an invasion of communism supported by the Soviet Union (Kieran, 1982). This resulted in an economic and political blockade by the West, leaving the Soviet Union and Vietnam to provide the only development assistance during this time (Vickery, 1986; for education see Clayton, 2000). It was only after the transitional period from 1989-1993, which included peace accords signed in 1991, the complete control of the country by the United Nations Transition Authority in Cambodia during 1992-1993, and finally the conduct of elections in 1993, that the Kingdom of Cambodia was recognized within international organizations and institutions.

Politically, Cambodia has remained under the tight control of a single ruler, Hun Sen, since 1985. He came to power with the Vietnamese occupation and has remained there through strategic alliances (e.g., with the Soviet Union, during the Cold War). Although there was social unrest during and after the 1993 and 1998 elections, Hun Sen has solidified his political power with each passing election through the politicization of the civil service, the military, and the police. It was only in the 2013 election that his political party, the Cambodian People's Party, saw its lowest election rate to parliament since the 1998 election when his party won majority control. Nevertheless, Hun Sen's power remains near absolute. As one interviewee noted, the longevity of Hun Sen's rule has meant the continuation of "authoritarian thought" because the current elite rose to prominence during the time of Vietnam's occupation (CAM10, 2-3).

One result of this "authoritarian thought" has been that criticism of the government and of politicians is not well tolerated and is often accompanied by harsh consequences. Freedom of the press is minimal, especially considering that political parties control most Khmer-language 
newspapers. ${ }^{3}$ This leads many people and organizations to be cautious when it comes to critiquing the actions and performance of those in power.

Another salient aspect of the contemporary political economy is that, since the early 1990s, NGOs and other development partners have had a significant degree of latitude to operate (Bandyopadhyay \& Khus, 2013; Dy \& Ninomyia, 2003). Given that the education sector was reestablished in the 1980s and that the capacity of the central government was extremely low at that time, these organizations were able to pursue their projects freely. One interviewee commented:

Ten years ago certainly. It was so easy. You run a small NGO, you get some money from wherever and you can do whatever you like, you know? Because you are sitting on this bag of money and everyone wants to have your money. And that time also the government capacity was just so weak (CAM3, 33).

Although the capacity of the government has increased significantly over the course of the previous two decades, as many interviewees attested, the government still relies on the capacity and technical expertise of international organizations. A prime example is that an education specialist from JICA works inside the Planning Department of MoEYS directly with the Director of Planning on key issues. International aid also continues to account for half of Cambodia's annual budget (Springer, 2011).

There has generally been an adversarial relationship between the government and NGOs, as the latter have frequently confronted and pressured the former on a range of issues. Due to this, and the fact that the Cambodian government does not tolerate criticism well, it has tried to control the NGOs - a difficult task given the total number of NGOs is estimated at 3,492 (Bandyopadhyay \& Khus, 2013). A recent attempt by the government has been the creation of an "NGO law," known as the Law on Association and Non-Governmental Organizations, that would have allowed the government to dissolve any NGO that it felt was harming (or not upholding) Cambodian culture and morality (CAM16). This effort produced a strong backlash, both domestically and internationally, and has been tabled by parliament as of this writing. Nevertheless, it indicates the government's stance towards NGOs generally. That said, NGOs in the education sector generally have a better relationship with the government for two reasons: (1) because these NGOs tend not to be as confrontational and critical (as, for example, labor unions or NGOs working on corruption, human trafficking, etc.) and (2) because the government sees education NGOs as key to providing a vital public service and as helping to meet international development targets, such as those in the Education for All (EFA) initiative and the Millennium Development Goals (MDGs).

\subsubsection{Educational governance elements}

Despite the progress made since the end of the Khmer Rouge, Cambodia's education system continues to face formidable challenges (Kitamura, Edwards, Chhin \& Williams, forthcoming). Student dropout and the transition from primary to secondary levels of education are key challenges (Chinnh \& Dy, 2009). Although the Education Management Information System, which is a database derived from schools and commonly used by MoEYS, reported a net enrollment rate of 96.4 percent in 2011, other data sources depict a different story: the Commune

\footnotetext{
${ }^{3}$ According to Reporters Without Borders' World Press Freedom Index 2014, Cambodia ranks 144 out of the 180 countries included (https://rsf.org/index2014/en-index2014.php).
} 
Database, which is a database compiled by commune offices, reported the enrollment at 87.9 percent, and the Cambodian Socio-Economic Survey, which is a national survey of households, reported the net enrollment rate at 84.3 percent (UNICEF, 2013). ${ }^{4}$

Another challenge is educational finance. The share of recurrent expenditures for MoEYS has decreased between 2007 and 2012 (with the exception of 2011, which saw a slight increase from the 2010 budget), despite the fact that the Cambodian economy has steadily increased since 1998 (Brehm, Silova \& Tuot, 2012). As a percentage of GDP, Cambodia's MoEYS receives less than half the world average ( 2.3 percent in 2012 compared to 4.8 percent) and less than the average for East Asia (3.8 percent; Edwards, 2012). Relatedly, corruption and the levying of unofficial fees are both deeply engrained in the education sector (Springer, 2011). Though the government has promised reform in this area, the extent of its action appears to be limited to rhetoric. Students continue to confront fees for educational services, including: registration and enrolment, classroom materials, examinations, lesson handouts, and exam papers (Bray \& Bunly, 2005; Brehm \& Silova, 2014; Brehm, Silova \& Tuot, 2012; Dawson, 2009)

Within the larger historical context, the structural conditioning of educational governance has been dominated by MoEYS and the development partners. These two groups of actors have, since the 1990s, developed a co-constitutive structure of educational governance. For instance, when the United Nations Children Fund (UNICEF) prioritized non-formal education in its international reform agenda, MoEYS responded by beginning a Department of Non-formal Education within its organizational structure. Likewise, the Joint Technical Working Group (JTWG, defined below) provides an avenue for the development partners to support the education sector plan developed by MoEYS. The two structures are intertwined and somewhat dependent on each other, and often actors participate across spaces. For its part, policy advice from non-ministry, civil society actors is generally non-critical if it is to be taken seriously by MoEYS. Evidencebased research and engagement through government-sanctioned processes are both acceptable practices, while pursuing openly critical and confrontational advocacy strategies are not. With this structural conditioning in mind, we now turn to the "new actors" and "new spaces" that have entered and impacted educational governance in recent years.

\subsection{Social interaction}

\subsubsection{New actors in Cambodian educational governance}

The evolution of Cambodia's education system in the post-conflict epoch has occurred in parallel with - and has been impacted by - the globalization of education policymaking (Burbules \& Torres, 2000; Rizvi \& Lingard, 2010). Consequently, a range of actors and ideas have been circulating within Cambodia and influencing the system's development. This is not to suggest, however, that actors within MoEYS have been ineffectual. To the contrary, interviewees repeatedly asserted that the most important person in the realm of education is MoEYS Secretary of State, Nath Bunroeun, whose biographical history suggests he is invested in the improvement of the education system. To be sure, he has placed much emphasis on channeling all available energies (from the government, development partners, NGOs) in order to meet the MDGs and EFA initiative. Having attended the 1990 conference on EFA in Jomtien, he has been a leader in the MoEYS for over two decades and thus a conduit through which the global circulates.

\footnotetext{
${ }^{4}$ See Brehm and Edwards (2014) for further discussion and examples of how the MoEYS manipulates such statistics.
} 
Numerous international organizations have also been integral, particularly UNICEF, the Swedish International Development Cooperation Agency, and the European Commission, each of which participates in up-stream policy discussions with the government, unlike other development partners. UNESCO, for its part, participates in processes of educational governance and advances particular interests, but is limited by a relatively small budget. In contrast, the World Bank, which has a comparatively large budget and a strong connection with the government, acts more independently by not engaging with formal processes to harmonize development partner assistance. Finally, the U.S. Agency for International Aid (USAID) and JICA primarily dedicate themselves to project implementation. Development assistance, of course, is not limited to the education sector-and as Springer (2011) notes, "international donors [have] provided over 50 percent of the government's annual budget for more than a decade" (p. 2561). Close relationships between the government and the development partners, as well as among the development partners themselves, can be attributed to the fact that many have been working in Cambodia for over two decades.

The civil society organization examined here- $\mathrm{NEP}$ - is thus a relatively new entrant to the politics of educational governance. This organization, which represents and works on behalf of all education-related NGOs, originated in 2002 with its raison d'etre to channel civil society feedback and interaction through a single organization. Both the government and the development partners were in favor of this, as the number of NGOs had grown exponentially and become unwieldy. With continued financial and technical support from international and national organizations alike, NEP has managed to survive (though at times barely, at least before 2009) and to grow from a coalition of 12 to 118 members by 2012.

As of 2012, NEP employed 15 personnel spread across four organizational areas: Research and advocacy, Educational Programming, Finance and Administration, and Membership and Communication. These areas are overseen by a Director and a Board of Directors, the latter of which has seven (inter)national members and is responsible for approving the budget, setting the direction for NEP, and approving policy changes. The director implements policy and oversees day-to-day operations. NEP's purpose is to engage with the government on education policy issues (particularly around quality and access), to advocate for civil society, and to augment the capacity of its members. Noticeably, however, prior to 2009, NEP was struggling both financially and in terms of its own capacity. On this latter point, the leadership style of the previous director of NEP (who served until early 2008) was drastically different from that of the director who took over in 2009. For example, the former director did not engage in collaboration with MoEYS, did not establish a common understanding between NEP and MoEYS regarding important issues and how they should be addressed, and did not develop a clear plan of action for NEP. Instead this director brought critical feedback to policy discussions with the government (CAM8, 1). Not surprisingly, NEP was not only failing to affect education governance processes more generally but was also failing at realizing its own mission. It was marginalized and ineffective in education governance, and it "almost disappeared," save for intervention by its Board of Directors, which managed the organization over for about six months during mid-year 2008 (CAM6, 13).

Since that time, NEP has hired a new, politically savvy director, who has engaged with MoEYS in a culturally sensitive manner, unlike his predecessor. In addition, the new director has been able to use the funds provided by GCE, as well as the (inter)national legitimacy that comes with a transnational partnership, to create new spaces within and outside NEP that it was able to leverage to gain a seat at the proverbial decision-making table of educational governance. We detail and further discuss these actions in later sections. 


\subsubsection{New spaces in Cambodian educational governance}

Education policy in post-conflict Cambodia has been influenced by the Sector Wide Approach (SWAP) to development, where the government and national and international stakeholders come together to plan and harmonize educational priorities, policies, and strategies (Brown et al. 2001). This has meant the creation of two working groups. The first is the Education Sector Working Group (ESWG). This group meets monthly and counts among its members UN and bi-lateral aid agencies as well as a few international NGOs. UNESCO has chaired the ESWG since November 2011 (prior to that, it was chaired by UNICEF). Through the ESWG, its members come up with direct feedback for the government on issues that are being discussed at the moment (usually those issues that the government prefers to discuss). Prime examples include the annual operating plan of the government or the Education Sector Plan. The second group is the JTWG, which can be defined as the ESWG plus the government. The Minister of Education chairs it and there are two vice-chairs - the MoEYS Secretary of State and the chair of the ESWG. There are sub-technical working groups under the JTWG for specific issues. In addition, there are two major events in the education sector held each year. There is the government's annual education retreat, which is a high-level event held over the course of a few days with a group of 20 stakeholders from within and outside government. There is also the annual education congress attended by MoEYS, development partners, and NGOs to look at "what works, what doesn't, and what should be improved" (CAM13, 7).

For our purposes, however, the most important point regarding the above is that NEP was awarded a permanent seat in both groups, attends the annual education retreat, and helps plan the education congress. NEP has, subsequently, been able to create and strategically use these new spaces to influence education governance processes and the making of education policy. Indeed, NEP often meets with directors from within MoEYS (e.g., directors of Primary Education and the Planning Department) to provide feedback on the specifics of certain policies and to share its own reports, which have been perceived as valuable (CAM5, CAM7). In view of these recent achievements, one can conclude that NEP has, especially considering Cambodia's authoritarian context, evolved from an organization on the fringe to one that has a voice and a place in educational governance. Put differently, NEP has succeeded in effecting structural elaboration by becoming both a key actor within - and an essential component of - the structures of education governance in Cambodia. We address how this happened below.

\subsubsection{The relational process of global educational governance}

GCE has been integral to NEP's transformation. This organization, in addition to being a transnational advocacy organization, is also "the globally recognized voice for civil society actors on the issue of Education for All" (Mundy, 2012, p. 17). Having itself begun in 1999, the GCE has "grown enormously ... [and now] has affiliated members in over 100 countries, including the participation of major international and regional non-governmental organizations" (p. 17). From this position, the GCE decided in the mid 2000s to enhance its support of national level education advocacy coalitions through the creation of the Civil Society Education Fund (CSEF), funded at USD\$17.6 million by the Fast Track Initiative. From 2009 to 2012 the funding was distributed to participating national coalitions, among which NEP was one. In terms of Archer's morphogenetic sequence (Figure 1) 2009 corresponds with $\mathrm{T}_{1}$ and 2012 corresponds with $\mathrm{T}_{4}$. 
NEP's participation in CSEF meant, in the first place, that its budget immediately doubled. ${ }^{5}$ Thus, not only did support by GCE lend NEP symbolic legitimacy in that the latter had the endorsement of an influential transnational actor, but GCE's financial support meant that NEP could bolster its core capacity. Indeed, NEP utilized the majority of the CSEF to cover the salaries of its key personnel and to hire three additional staff members in the areas of research coordination, advocacy, and financial management. Beyond this, however, CSEF also entailed the support of regional organizations linked with GCE. Given its geographic location, NEP has worked with the Asia South Pacific Association for Basic and Adult Education (ASPBAE) - with assistance being in the form of monitoring, coaching, and regional workshops where, in the case of the latter, information, lessons, and strategies are shared with and among national coalitions from across the region.

NEP has taken the financial and institutional resources afforded by CSEF and carefully used them to expand its strategic activities in the areas of research, campaigns, and policy engagement. Importantly, over the course of CSEF, by initially concentrating its energies on research and campaigning, it has later been able to access and create spaces where policy engagement with the government and development partners occurs. A key point is that, with assistance from GCE in the form of the CSEF, NEP was able to sufficiently elevate its stature such that it was recognized as a relevant actor in relation to education governance. This would then be followed by strategic social interaction aimed at structural elaboration.

In terms of research, CSEF not only made it possible to hire a research coordinator in 2009, but it also increased NEP's ability to carry out its own studies, from which it produces 2-3 reports annually. The reports' foci are intended to overlap with NEP's top advocacy priorities but are nevertheless influenced by non-national actors through its regional and global connections from the GCE. Notably, the importance of NEP's research has increased since 2009 and has resulted in NEP working with international organizations like Volunteer Service Overseas to find international volunteers to build the capacity of its research department. ${ }^{6}$ In terms of NEP's legitimacy, the fact that it has the consistent ability to carry out policy-relevant studies has placed the institution in a positive light, contributing to its rising profile. Relatedly, when NEP now researches an issue, it adds to the gravity of that particular issue among stakeholders in the education sector both inside Cambodia and on the global scale through GCE. For instance, NEP's report on informal fees was published by ASPBAE as part of its Asian South-Pacific Education Watch initiative (NEP, 2007). Even though NEP's research is not on par with development partners' larger and more expensive studies, the fact that NEP is researching an issue adds weight to it because doing so shows that civil society is aware of and focused on certain problems (CAM11, 29). Finally, NEP's research has helped to reinforce and elevate its position in the ESWG and JTWG. Studies on school fees and teacher motivation were particularly impactful in this regard (CAM19, int2).

Campaigning is the way that NEP highlights certain issues, with events and actions being targeted at the government itself and/or the general public. These events and actions tend to relate to themes that have been established by GCE. NEP has gained recognition for hosting wellexecuted promotional and informational events for representatives of the government, development partners, and civil society groups, as well as for the public at large. Examples include

\footnotetext{
${ }^{5}$ For details see Edwards (2012).

${ }^{6}$ Volunteer Service Overseas is an international federation of non-governmental organizations that recruits skilled volunteers to work in developing countries for two years.
} 
media productions (e.g., television segments about inclusive education, radio programs about teaching for gender equity); student enrolment campaigns; and special events for World Teacher Day, Literacy Day, and Global Action Week (GAW). Specifically, for 2011's GAW-which focused on gender marginalization, per GCE's choosing-NEP organized a launch event for 174 education stakeholders (including high-level members of the MoEYS and development partners), held workshops for civil society organizations, created and distributed 10,000 posters on education-related gender issues, and produced a book of personal stories on gender discrimination. It has gotten to the point where multiple TV stations will now cover NEP's special events. Moreover, NEP is now able to recruit the MoEYS' Secretary of State and other top education officials to speak at ceremonies.

The aforementioned research and campaign (or general advocacy) activity during 20092011 garnered respect and credibility for NEP, which in turn has helped to open more doors for policy engagement at new levels. In other words, initial social interaction in the form of research and advocacy enabled NEP to engage in additional forms of social interaction that brought it into close and consistent contact with the existing actors and structures of education governance. Thus, during this time (which we can think of as spanning $T_{2}$ and $T_{3}$ ), NEP's agency worked through education governance processes and structures that were facilitated by the global (i.e., GCE) and constrained by the local (i.e., the position of NGO's vis-à-vis the government).

Following on this strategic and purposeful engagement, NEP finally, and crucially, attained a permanent seat on the ESWG and JTWG. That is, through its ability to consistently demonstrate its relevance and usefulness with regard to research, analysis, and policymaking, which was in turn made possible in part through its connections with GEC, NEP became a fixture of the education governance spaces and processes that impact education politics and that facilitate education policy formation in Cambodia. To state this more directly: By $2012\left(\mathrm{~T}_{4}\right)$, NEP had been formally integrated into the official structure of education governance, thereby modifying that structure in the process.

Having identified the sequence of events that lead to structural elaboration, we further discuss in the next section the tensions that were evident between morphostasis and morphogenesis and how NEP responded to them in order to achieve structural change.

\section{Morphostasis versus morphogenesis in Cambodian educational governance}

Analytically, the emergence of civil society in the education sector in Cambodia reveals, first, that the transition from social interaction to structural elaboration (or morphogenesis) is mediated by historical structures and, second, that civil society actors, or any new entrant, must often accommodate this structure before it can modify it, particularly in repressive contexts like that of Cambodia. Put differently, in the case of Cambodia, while NEP has more recently been able to push, in its own way, for structural elaboration, it first had to demonstrate its ability and willingness to serve the interests of the status quo (structural reproduction). NEP had to do this because other approaches - such as confronting the government or working outside the development partnerswould only have resulted in NEP's continued marginalization, as was the case for NEP under its director prior to 2009.

A consequence of serving the status quo, however, is the possibility of civil society institutions becoming a mouthpiece for the government. By NEP's own admission, they purposefully became a non-threatening complement to the machinery of educational governance. To that end, NEP's director commented: "[Advocacy_- ] its a little bit about strategizing, especially 
because in the past, you know, we say, 'okay the government wants to do something,' and then we do advocacy based on that" (CAM19, int1). One outcome of this approach has been the government's inclination, in turn, to engage with NEP. For example, whereas the government previously declined offers to join in NEP's research planning activities, they now participate. Of course, as a result of these dynamics, NEP ran the risk of only reproducing the government's perspective; yet, NEP had to first engage in this way in order to access and then to become part of the existing structures, for only then could it pursue a strategy of being tactfully critical.

Since 2009, NEP has positioned itself as an extension of the official structure of educational governance and, over time, gained the trust of MoEYS. NEP was able to gain this trust by responding appropriately to the structural conditions of the context within Cambodia and by strategically employing the resources made possible through its relationship with GCE. In elaborating on the relationship between NEP and MoEYS that has resulted, NEP's director echoed an observation made by numerous interviewees:

For example, like teacher policies, they put the name of NEP in the small working group as well as in the technical working group .... In the retreat, they [MoEYS] say, "okay, NEP has to be there." In the committee they formed to prepare for the education congress, they also have NEP there. And the midterm review ..., they also invite NEP. So every time they have meeting or consultation or develop any new policy or revise policy or somethingthe name of NEP always appears in the list of invitations. (CAM19, int1, 21)

To continue, NEP's service to the structure is further evident on two accounts. First, MoEYS sees NEP as the coordinator and filter for education NGOs_-as evidenced by the fact that, when a local NGO attempted to communicate directly with the MoEYS, that NGO was told, "No, don't talk to us, talk to NEP. NEP will talk to us" (CAM11, notes). Secondly, MoEYS utilizes NEP as a means to reach out to other education NGOs across the country (CAM7, 1).

NEP has thus cooperated with MoEYS on its initiatives and has served as a conduit through which the government can access the capacity and knowledge of education NGOs more broadly. Because NEP has acted as a facilitator of "practical" information from those areas of the country where the government has difficulty monitoring (there are over 6,449 primary schools), it is seen as a "good partner" by the government and has become one of the three main pillars of the education sector, along with development partners and MoEYS.

Only once reaching this point, where NEP was considered one of the three pillars of the education sector, could NEP be formally incorporated into the structure of education governance, an act which was made official by its attainment of a permanent seat in the ESWG and JTWG during the first quarter of 2012 (CAM19, int2, 8-9). The importance of this result should not be understated, for these two spaces represent the pinnacle of Cambodian education politics. Subsequently, from this position, NEP has been able to shift from structural reproduction to structural elaboration.

To that end, for example, it could begin to focus on raising its concerns and pushing to change both the dynamics of educational governance as well as the content of education policy itself, though this has had to be done in ways that are sensitive to the nature of the context. As one representative of NEP stated, "[we] want to convince the government in a way that won't upset the government" (CAM10, 02). This often means working closely with the technical departments of MoEYS and voicing feedback in the form of suggestions. NEP's director explained the dynamic this way: 
We $[(\mathrm{NEP})]$ try ... to make sure that we include as much input as possible from the other side [(i.e., MoEYS)] into the draft policy developed by development partners. .... For example, ... child friendly schools ..., we work with the Department of Primary Education. We raise our concern, you know, we raise them together. And sometimes we also invite them to conduct a presentation for us, and during that time [NGO] members can make some suggestions and ask some questions and so on. So this is another way, you know, to provide input through the technical department. (CAM19, int1, 12-13)

Yet the clearest evidence of NEP's growth and changing role came from the development partners themselves. Whereas NEP previously had to work through the development partners, they can now push for change on their own. On this point, the words of an education specialist from ADB are particularly revelatory:

Before [a] couple years ago [MoEYS would] ... not consider the point raised by NEP .... [unless] the donors support that point. So, basically, I told NEP, if you find anything interesting, you have to convince DP [development partners] and DP will... I mean donors like ADB, World Bank, [those] more influential to the government - send through them, if they support. But now they [NEP] can even do it. You know they can say "hey government! What I have done, we have a team of professionals ... This is evidence-based, ... I just want to let you know - and if ... you need justification, you need any information from this finding, ... they are ready." You know, they say "Take it, this is my recommendation. Take it." You know, you are not feeding the government, but make the food available if they want to eat, and you know they have choices. (CAM8, 4)

Clearly, then, by integrating itself into the structural conditioning of educational governance over time NEP can now separate itself a bit. It can now plan its own initiatives and strategies for engagement with the government, such as research dissemination events and work with MoEYS departmental directors. The morphogenetic sequence thus begins anew.

As the newest part of the structure of educational governance in Cambodia, NEP's ability to effect morphogenesis is evident. The fact that NEP now comprises one of the three pillars of educational governance signals that the structure has, in fact, been modified, which will necessarily affect the agency of all those involved in educational governance just as the initial structural conditioning affected the agency of NEP. Into the future, it remains to be seen whether NEP can engender further structural elaboration.

It should be remembered though, that NEP's ability to become part of the structure of educational governance in Cambodia was significantly influenced by the GCE generally and the CSEF in particular. The agency that produced morphogenesis would have been impossible without GCE's transnational support of NEP through the CSEF, which provided more than financial infusions. As noted, it also allowed members of NEP to learn from and increase its capacity through regional and international meetings of civil society, such that it could more effectively engage with the MoEYS and development partners' structure in Cambodian educational governance.

\section{Conclusions}


The critiques highlighted at the outset of this manuscript emphasize a particular idea with regard to analysis in the social sciences generally and in global and comparative education studies specifically. As noted, the idea is thus: Rather than focus on (supposedly) static units, scholars would do well to conceptualize phenomena for analysis that are fluid in nature and which are impacted by a range of pressures. Appadurai (2013) employs the concept of geographies to refer to such phenomena, wherein a geography of interest can be thought of as a terrain of social engagement. While this terrain is inscribed with the histories that produced it, it is also terrain that continues to develop as it comes into contact with - and is co-constituted by - other actors and structures.

Yet, faced with this proposal for how we should conceive of those phenomena which ought to be investigated and compared, the question becomes how, exactly, in analytical terms, to put into practice the two core elements of Appadurai's (2013) conceptualization-namely, structure and agency. In the present paper, we attempted to demonstrate the value of Margaret Archer's morphogenetic approach for answering this question by applying it to the emergence of civil society in Cambodian education governance (the social terrain of interest). In our case, we began to engage with this approach by first identifying the relevant socio-cultural and political-economic structures within which Cambodian education governance is embedded. Next, we identified additional structures by examining in what arrangements and in which spaces global education actors engage in Cambodian education governance.

Analytically, we were then able, in accordance with Archer's (2010a, b) morphogenetic approach, to (temporarily) hold those structures constant. This was necessary in order to separate structure from agency - that is, in order to investigate and explain the types of social interaction that characterized Cambodian education governance during the time period of interest, with particular attention to the role of civil society. In so doing, we were able to identify the underlying sequence of social interaction between times $T_{1}$ (2009) and $T_{4}$ (2012) that eventually lead to structural elaboration, where this was represented by NEP becoming one of the three pillars of the education sector, along with the government and the development partners.

Looking beyond the case of civil society in Cambodia, we suggest that the morphogenetic approach can usefully contribute to studies of global education governance more generally. One reason for this suggestion stems from the salience of the critiques and concepts offered by Arjun Appadurai. An additional reason relates to the important issue of time in educational policy studies - an issue which studies of global education governance largely avoid. Often, even where scholars consider with the dynamics of global education governance over a period of years, they neither make clear their conception of time nor, perhaps more importantly, the way that they analytically distinguish between structure and agency in relation to the passage of time.

Archer's (2010a,b) strategy thus provides a way forward. In contrast to Giddens' (1979) structuration theory, where structure and agency develop simultaneously and cannot be artificially separated, the morphogenetic approach recognizes chronological time as diachronic in nature, although makes possible the isolation of a synchronic moment for the purpose of analyzing social interaction in relation to pre-existing structures. For this reason, we see Archer's (2010a,b) approach as particularly useful.

Yet, while we have attempted to take a step forward by employing the morphogenetic approach in the study of global education governance, there is more work to be done-that is, a number additional questions remain. For example: What is lost in using only a chronological conception of time in order to conduct our analyses of structural and agentic change? In what ways can - and does - the agency of national actors at times serve as an extension of trans-national 
structures? And in which circumstances do structures experience morphostasis instead of morphogenesis? Finally, going forward, an interesting and important avenue for research is to account for how semiotics and discourse should be incorporated into discussions of morphogenesis - particularly as they may constitute a formidable (ideational) structures in their own right that condition the possibilities of societal change in general and educational change in particular.

\section{Bibliography}

Appadurai, A. (2013). The future as cultural fact: Essays on the global condition. New York: Verso.

Archer, M.S. (2010a). Morphogenesis versus structuration: On combining structure and action. The British Journal of Sociology. 61, 225-252.

Archer, M.S. (2010b). Routine, reflexivity, and realism. Sociological Theory, 28(3), 272-303.

Archer, M.S. (1982). Morphogenesis versus structuration: On combining structure and action. The British Journal of Sociology, 33(4), 455-483.

Brehm, W.C. and Edwards Jr., D.B. (2014). The many space of learning: Private tutoring and post-2015 Education For All, Norrag News, 50, 56-58.

Brehm, W. C. and Silova, I. (2014). Hidden privatization of public education in Cambodia: Equity implications of private tutoring, Journal of Educational Research Online, 6 (1), 94-116.

Brehm, W.C., Silova, I. and Tuot, M. (2012). The Public-Private Education System in Cambodia: The impact and Implications of Complementary Tutoring. London: Open Society Institute.

Ayers, D.M. (2000). Tradition, modernity, and the development of education in Cambodia. Comparative Education Review, 44(4), 440-463.

Ball, S.J. (2012). Global education inc.: New policy networks and the neoliberal imaginary. New York: Routledge.

Bandyopadhyay, K.K. and Khus, T.C. (2013). Changing civil society in Cambodia: In search of relevance. Development in practice, 23(5-6), 665-677.

Bartlett, A.J., Clemens, J. and Roffe, J. (2014). Lacan, Deleuze, Badiou. Edinburgh: Edinburgh University Press.

Bray, M., and Bunly, S. (2005) Balancing the books: Household financing of basic education in Cambodia. Hong Kong: Comparative Education Research Centre, The University of Hong Kong.

Brickman, W.W. (1960) A Historical Introduction to Comparative Education, Comparative Education Review, 3(3), 6-13.

Brown, A., Foster, M, Norton, A., and Naschold, F. (2001). The Status of sector wide approaches, working paper 142. London: Overseas Development Institute.

Burbules, N.C. and Torres, C.A. (2000). Globalization and education: Critical perspectives. New York: Routledge.

Carney, S. (2009). Negotiating policy in an age of globalisation: Exploring educational 'policyscapes' in Denmark, Nepal, and China. Comparative Education Review, 53(1), 6388.

Chinnh, S. and Dy, S. (2009). Education reform context and process in Cambodia. In Y. Hirosato and Y. Kitamura (Eds.), The political economy of educational reforms and capacity development in Southeast Asia: Cases of Cambodia, Laos, and Vietnam (pp. 113-130). Springer.

Clayton, T. (2000). Education and the politics of language: Hegemony and pragmatism 
in Cambodia, 1979tiona. Hong Kong: Comparative Education Research Centre, The University of Hong Kong.

Dale, R. (2005). Globalisation, knowledge economy and comparative education. Comparative Education, 41(2), 117-149.

Dale, R. (2007). Globalization and the rescaling of educational governance: A case of sociological ectopia. In C.A. Torres \& A. Teodoro (Eds.) Critique and utopia (pp. 35-44). Lanham, MD: Rowman \& Littlefield.

Dale, R. and Robertson, S.L. (2007). "Beyond methodological 'isms' in Comparative Education in an era of globalisation." in A. Kazamias and R. Cowan (eds), Handbook on comparative education (pp. 19-32). Netherlands: Springer.

Dawson, W. (2009). "The tricks of the teacher: Shadow education and corruption in Cambodia" in (pp. 51-74. )S. P. Heyneman (ed.), Buying your way into heaven: Education and corruption in international perspective, Rotterdam: Sense Publishers.

Dy, S. S., and Ninomiya, A. (2003). Basic education in Cambodia: The impact of UNESCO on policies in the 1990s. Education Policy Analysis Archives, 11(48), 1-20.

Easton, D. (1959). The political system: An inquiry into the state of political science. New York: Knopf.

Edwards Jr., D.B. (2012). CSEF Evaluation: Cambodia. Universitat Autónoma de Barcelona.

Edwards Jr., D. B. (2013). International processes of education policy formation: An analytic framework and the case of Plan 2021 in El Salvador, Comparative Education Review, 57 (1), 22-53.

Giddens, A. (1979). Central Problems in Social Theory: Action, Structure and Contradiction in Social Analysis. London: Macmillan.

Graeber, D. (2001). Towards an Anthropological Theory of Value: The False Coin of Our Own Dreams. New York: Palgrave.

Jones, P. W. (2007a). Education and world order, Comparative Education, 43 (3), 325-337.

Jones, P.W., (2007b). World Bank financing of education: Lending, learning and development, ( $2^{\text {nd }}$ ed.). London: Routledge.

Kiernan, B. (1982). William Shawcross, declining Cambodia. Bulletin of Concerned Asian Scholars, 18(1), $56-63$.

Kitamura, Y., Edwards Jr., D. B., Chhinn, S., and Williams, J. (Eds.) (forthcoming). The political economy of schooling in Cambodia: Issues of equity and quality. New York: Palgrave MacMillan.

Lingard, B. \& Rawolle, S. (2011). New scalar politics: Implications for education policy, Comparative Education, 47 (4), 489-502.

Mundy, K. (2012). The Global Campaign for Education and the realization of "Education for All. In Verger, A. and M. Novelli (eds). 2012. Campaigning for 'Education For All': Histories, strategies and outcomes of transnational social movements in education. Sense: Rotterdam.

Mundy, K. and Ghali, M. (2009). International and transnational policy actors in education: A review of the research. In G. Sykes, B. Schneider, and D.N. Plank (eds.) Handbook of education policy research (pp. 717-734). New York: Routledge.

Mundy, K. and Murphy, L. (2001) Transnational advocacy, global civil society? Emerging evidence from the field of education. Comparative Education Review, 45(1), 85-126.

Mysliveic, E. (1988). Punishing the poor: The international isolation of Kampuchea. Oxford: Oxfam. 
NEP. (2007). Cambodia summary report: The impact of informal school fees. Mumbai, India: ASPBAE.

Rizvi, F. and Lingard, B. (2010). Globalizing education policy. New York: Routledge.

Sassen, S. (2006). Territory, authority, rights. Princeton, NJ: Princeton University Press.

Sellar, S. and Lingard, B. The OECD and global governance in education. Journal of Education Policy, 28(5), 710-725.

Springer, S. (2011). Articulated neoliberalism: the specificity of patronage, kleptocracy, and violence in Cambodia's neoliberalization. Environment and planning A, 43, 2554-2570.

UNICEF (2013). Presentation to the Education Sector Working Group, Phnom Penh, Cambodia.

Urry, J. (2003). Social networks, travel and talk. British Journal of Sociology, 54(2), 155-75.

Verger, A. (2012). Framing and selling global education policy: The promotion of public-private partnerships for education in low-income contexts. Journal of Education Policy, 27(01): 109-130.

Verger, T. and Novelli, M. (2012). Campaigning for 'Education for All': Histories, strategies and outcomes of transnational advocacy coalitions in education. Rotterdam: Sense Publishers.

Verger, T., Novelli, M. and Altinyelken, H.K. (Eds). (2012). Global education policy and international development: New agendas, issues and policies. London: Bloomsbury.

Vickery, M. (2010). Kicking the Vietnam Syndrome in Cambodia. Retrieved from http://michaelvickery.org/ on November 27, 2013.

Vickery, M. (1986). Kampuchea, politics, economics, and society. London: Frances Pinter (Publishers).

Webb, P.T. and Gulson, K.N. (2013). Policy intensions and the folds of the self. Educational Theory, 63(1), 51-67.

Willmott, R. (2002). Education Policy and Realist Social Theory: Primary Teachers, Childcentred Philosophy and the New Managerialism. New York: Routledge. 